\title{
MODEL PEMBELAJARAN CONTEXTUAL TEACHING AND LEARNING (CTL) UNTUK MENINGKATKAN PRESTASI BELAJAR
}

\author{
Gusti Ketut Sriariati \\ email: gustiketutsriariati2018@gmail.com
}

\begin{abstract}
ABSTRAK
Sebagian besar siswa di kelas V Semester IISD No. 2 Mambal Tahun Pelajaran 2015/2016 belum mencapai tingkat ketuntasan belajar yang ditetapkan di sekolah ini yaitu 73. Dari kekurangan yang ada di lapangan tersebut, peneliti mengupayakan sebuah kajian ilmiah dengan melakukan penelitian tindakan kelas. Tujuan penelitian yang dilakukan ini adalah untuk meningkatkan prestasi belajar siswa kelas V Semester IISD No. 2 Mambal Tahun Pelajaran 2015/2016 dengan penggunaan model Pembelajaran Contextual Teaching And Learning (CTL) dalam pelaksanaan proses belajar mengajar. Penelitian yang dilakukan dalam dua siklus menggunakan tahapan perencanaan, pelaksanaan, observasi/pengamatan dan refleksi pada setiap siklusnya memfokuskan pencairan datanya menggunakan tes prestasi belajar dan melaksanakan analisis dengan analisis deskriptif. Setelah dilakukan refleksi, terjadi peningkatan prestasi siswa dari rata-rata nilai 68,15 meningkat menjadi 71,60 rata-rata kelasnya pada siklus I dan pada siklus II meningkat menjadi 78,45. Data tersebut menunjukkan keberhasilan pelaksanaan penelitian sesuai indikator yang dicanangkan. Akhirnya peneliti berkesimpulan bahwa penggunaan model Pembelajaran Contextual Teaching And Learning (CTL) dengan optimal dalam pelaksanaan proses pembelajaran dapat meningkatkan prestasi belajar IPS siswa kelas V Semester II SD No. 2 Mambal Tahun Pelajaran 2015/2016.
\end{abstract}

Kata kunci : Model Pembelajaran Contextual Teaching And Learning (CTL), Prestasi Belajar

\begin{abstract}
Most of the students in Grade V Semester II SD No. 2 Mambal 2015/2016 Academic Year has not yet reached the level of learning completeness set at this school, which is 73. From the shortcomings in the field, researchers seek a scientific study by conducting classroom action research. The purpose of this study is to improve student achievement class $V$ Second Semester SD No. 2 Mambal Year 2015/2016 Lesson with the use of Contextual Learning Teaching And Learning (CTL) model in the implementation of teaching and learning process. Research conducted in two cycles using planning, implementation, observation and reflection on each cycle focuses its data collection using learning achievement test and conducting analysis with descriptive analysis. After the reflection, an increase in student achievement from the average value of 68.15 to 71.60 average class in cycle I and on the second cycle increased to 78.45. The data shows the successful implementation of the research according to the indicator that is proclaimed. Finally, the researcher concluded that the optimal use of the Contextual Teaching And Learning (CTL) Learning model in the implementation of the learning process could improve the social studies learning achievement of the fifth grade students of SD Semester II. 2 Mambal Lesson Year 2015/2016.
\end{abstract}

Keywords: Contextual Teaching And Learning (CTL) Learning Model, Learning Achievement 


\section{PENDAhUluan}

Sebagai guruperlu upaya meningkatkan keilmuan dimana sebagai seorang guru harus mengetahui metode ajar; harus menguasai model pembelajaran; penguasaan teori-teori belajar; penguasaan teknik-teknik tertentu; pemahaman mengenai peran, fungsi serta kegunaan mata pelajarannya. Apabila betul-betul guru menguasai dan menerapkan tentang hal-hal tersebut dapat diyakini bahwa prestasi belajar peserta didik pada mata pelajaran IPS tidak akan rendah. Namun kenyataannya, perolehan data awal sebagai hasil observasi yang dilakukan ditemukan kenyataan bahwa prestasi belajar siswa kelas VSemester II SD No. 2 Mambal Tahun Pelajaran 2015/2016 baru mencapai nilai 68,15 dengan tingkat ketuntasan belajar yang hanya mencapai $30,00 \%$. Hasil tersebut masih sangat jauh dari ketetapan standar minimal pencapaian mutu pendidikan yang ditetapkan di SD No. 2 Mambal Pada mata pelajaran IPS yang nilai KKMnya adalah 73. Kelemahan proses pembelajaran yang terjadi selama ini yang menyebabkan rendahnya prestasi belajar siswa dikarenakan masih rendahnya kemauan guru untuk menerapkan model dan strategi pembelajaran yang aktif dan efektif untuk siswa. Masih banyak guru lebih cenderung berperan sebagai penyampai materi ajar ketimbang sebagai seorang guru sejati yang seharusnya bertugas sebagai pendidik dan pengajar.

Agar mampu memenuhi tujuan yang telah ditetapkan dan membantu siswa kelas V Semester IISD No. 2 Mambal Tahun Pelajaran 2015/2016mencapai hasil yang diharapkan peneliti sebagai guru mencoba melakukan perbaikan dengan menerapkan model pembelajaran Contextual Teaching
AndLearning (CTL). Peningkatan mutu pendidikan diupayakan untuk meminimalisir kesenjangan antara harapan dengan kenyataan lapangan maka peneliti berupaya mencarikan jalan keluar dengan harapan agar upaya yang dilakukan dapat dimanfaatkan secara terus-menerus dan dapat dijadikan bahan acuan untuk memecahkan permasalahan yang dihadapi. Hal ini dilakukan lewat sebuah penelitian tindakan kelas.Mengingat permasalahan yang ada adalah permasalahan yang mendesak untuk dipecahkan maka penelitian ini menjadi penting untuk dilaksanakan.

Berdasarkan latarbelakang masalah dapat disampaikan rumusan masalah sebagai berikut : Apakah penggunaanmodel pembelajaran Contextual Teaching And Learning (CTL)dengan optimal dapat meningkatkan prestasi belajar IPS siswa kelas VSemester IISD No. 2 Mambal Tahun Pelajaran 2015/2016?

Berdasarkan permasalahan diatas maka tujuan penelitian tindakan kelas ini adalah sebagai berikut : Untuk meningkatkan prestasi belajar IPSsiswa kelas VSemester IISD No. 2 Mambal Tahun Pelajaran 2015/2016 dengan penggunaan model pembelajaran Contextual Teaching And Learning (CTL)secara optimal dalam pembelajaran.

Pelaksanaan penelitian diupayakan agar dapat bermanfaat dalam pengembangan profesi keguruan. Dengan demikian manfaat penelitaian ini diharapkan dapat dirasakan bagi berbagai kalangan seperti,Bagi siswa, penelitian dengan menggunakanmodel pembelajaranContextual Teaching And Learning (CTL) pada mata pelajaranIPS dapat meningkatkan prestasi belajar.Bagi 
Guru, hasil penelitian ini dapat dipergunakan sebagai alternatif solusi penanggulangan permasalahan pembelajaran, dan secara serta merta mengindikasikan profesionalitas guru kelas dalam pengelolaan dan peningkatan kualitas pembelajaran.Bagi sekolah, hasil penelitian dapat dipergunakan sebagai refrensi dalam menanggulangi permasalahan rendahnya outpot dan outcome pendidikan di sekolah ini.

Model pembelajaran Contextual Teaching And Learning (CTL) didasarkan pada filosofi bahwa pengetahuan dibangun oleh manusia sedikit demi sedikit, hasilnya diperluas melalui konteks yang terbatas (sempit) dan tidak sekonyong-konyong. Pengetahuan bukanlah seperangkat faktafakta, konsep atau kaidah yang siap untuk diambil dan diingat. Konsep belajar yang mengaitkan antara materi yang diajar dengan situasi dunia nyata siswa perlu dilakukan guru (Depdiknas, 2002).

Joyce dan Weil (dalam Soli Abimanyu, 2008:2-4) mengatakan model pembelajaran adalah kerangka konseptual yang melukiskan prosedur yang sistematis dalam mengorganisasikan pengalaman belajar untuk mencapai tujuan belajar tertentu yang berfungsi sebagai pedoman bagi para perancang pembelajaran dan para pengajar dalam merencanakan dan melaksanakan aktivitas pembelajaran.

Elaine (2002 : 58) menyatakan bahwa Model pembelajaran Contextual Teaching And Learning (CTL)adalah sebuah sistem yang sesuai dengan cara kerja otak manusia, menyusun pola-pola yang mewujudkan makna dengan menghubungkan muatan akademik dengan kontek dari kehidupan sehari-hari siswa.

Berdasarkan pendapat para ahli di atas, maka dapat disimpulkan bahwa model pembelajaran Contextual Teaching And Learning(CTL) adalah konsep belajar yang membantu guru mengkaitkan antara materi yang diajarkanya dengan situasi dunia nyata siswa dan mendorong siswa membuat hubungan antara pengetahuan yang dimilikinya dengan penggunaan dalam kehidupan sehari-hari.

Abin Syamsuddin Makmun (2000 : 430) mengatakan bahwa prestasi belajar adalah kecakapan nyata (actual ability) yang menunjukan kepada aspek kecakapan yang segera dapat didemonstrasikan dan diuji sekarang juga atau dengan kata lain prestasi belajar adalah kemampuan seseorang dalam menguasai suatu masalah setelah melalui ujian tertentu. SedangkanMenurut Bustalin (2004:11) menjelaskan bahwa prestasi belajar siswa merupakan hasil yang diperoleh dari proses belajar mengajar. Prestasi belajar siswa adalah perubahan dalam hal kecakapan tingkah laku ataupun kemampuan yang dapat bertambah selama beberapa waktu dan tidak disebabkan oleh proses pertumbuhan, tetapi adanya situasi belajar, perwujudan dalam bentuk hasil proses belajar tersebut dapat berupa pemecahan lisan atau tulisan, dan ketrampilan serta pemecahan masalah yang langsung dapat diukur atau dinilai dengan menggunakan tes-tes yang berstandar.

Jadi prestasi belajar dapat diartikan sebagai hasil yang diperoleh dari perubahan penguasaan pengetahuan atau keterampilan yang dikembangkan melalui mata pelajaran berupa nilai tes atau angka yang diberikan oleh guru. Dengan demikian, dalam belajar terjadi perubahan dalam kebiasaan, kecakapan-kecakapan (skills) atau mendapat aspek pengetahuan (kognitif), sikap (affektif) dan ketrampilan 
(psikomotorik) yang diperoleh karena sengaja dan bukan karena proses pertumbuhan yang bersifat fisiologis atau proses kematangan.

Sesuai uraian materi yang telah disampaikan dapat dirumuskan hipotesis tindakan seperti berikut ini :Jika model pembelajaran Contextual Teaching And Learning (CTL)digunakan dengan mengacu pada teori ahli maka dapat meningkatkan prestasi belajar IPSsiswa kelas VSemester IISD No. 2 Mambal Tahun Pelajaran 2015/2016.

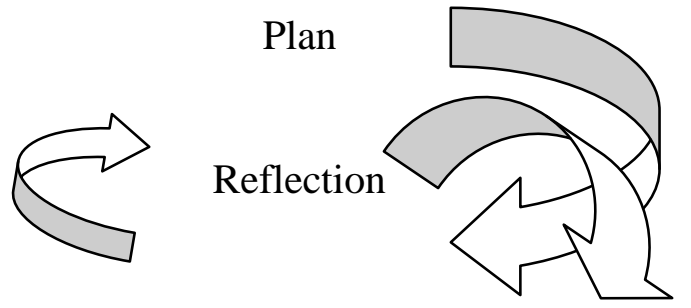

Revised Plan
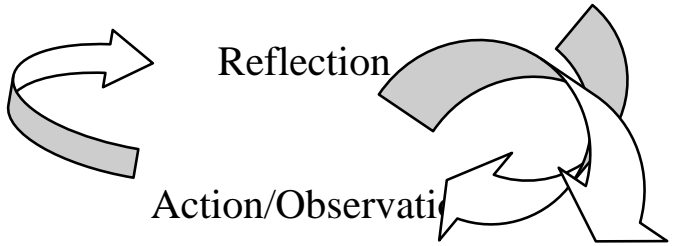

Revised Plan

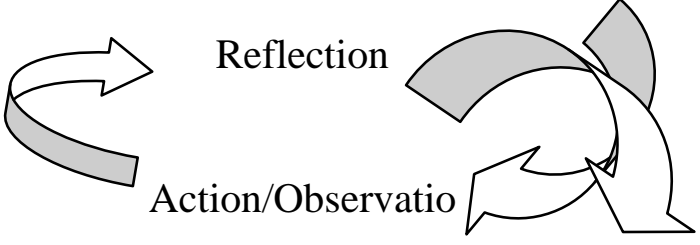

Gambar 01. Rancangan

Model

Penelitian Tindakan Kelas Oleh Hopkins (1992 dalam Masnur Muslich, 2011: 43)

Adapun subjek penelitian ini adalah siswa kelas VSemester IISD No. 2 Mambal Tahun Pelajaran 2015/2016. Penelitian ini dilakukan dari bulan Januari sampai bulan Apriltahun 2016.

Cara yang dilakukan dalam mengumpulkan data hasil penelitian ini adalah tes prestasi belajar.Metode yang digunakan untuk menganalisis data hasil

\section{METODE PENELITIAN}

Penelitian ini mengambil lokasi di SD No. 2 Mambal. Lingkungan sekolah tempat dilakukan penelitian ini cukup baik dalam mendukung lancarnya pelaksanaan proses belajar mengajar karena aman, nyaman, rindang, tidak bising serta masyarakat sekitar medukung keberadaan sekolah dengan baik. Rancangan dalam penelitian ini dikutip dari ahli yang bernama Hopkin seperti terlihat pada gambar di bawah ini.

penelitian ini adalahadalah metode deskriptif. Untuk data kuantitatif dianalisis dengan mencari mean, median, modus, serta menyajikan semua data dalam tabel untuk selanjutnya dibuat gambar grafiknya.

Indikator keberhasilan penelitian yang diusulkan tingkat keberhasilannya per siklus yaitu untuk prestasi belajar siswa diharapkan pada siklus I mencapai nilai73 dan pada siklus II mencapai nilai rata-rata 73 atau lebih dengan ketuntasan belajar minimal $85 \%$.

\section{HASIL PENELITIAN DAN PEMBAHASAN}

\section{Hasil Penelitian}

\section{Deskripsi Awal}

Dari perolehan data awal siswa kelas V semester IISD No. 2 Mambal Tahun Pelajaran 2015/2016 dapat disampaikan adalah dari 20 siswa yang diteliti, baru 10siswa yang mampu mencapai ketuntasan belajar pada mata pelajaran IPS. Perolehan rata-rata prestasi belajarnya baru mencapai 68,15 dengan prosentase $30,00 \%$ dan hasil tersebut masih jauh di bawah KKM yang telah ditentukan di sekolah ini yaitu 73. Untuk itu, hasil tersebut menunjukkan bahwa prestasi belajar 
siswa belum sesuai dengan yang diharapkan.Para siswa masih beranggapan bahwa mata pelajaran IPS merupakan mata pelajaran membosankan, sehingga tanggapan tersebut berdampak terhadap prestasi belajar mereka yang kurang memuaskan. Berangkat dari permasalahan tersebut maka peneliti selaku guru mengupayakan sebuah perbaikan pembelajaran dengan memaksimalkan.

\section{Deskripsi Siklus I}

\section{a. Perencanaan I}

Melihat permasalahan yang terjadi dalam pembelajaran awal, maka pada siklus I ini direncanakan halhal sebagai berikut :Menyusun Rencana Pelaksanaan Pembelajaran (RPP). Mempelajari langkahlangkah penggunaanmodel pembelajaran Contextual Teaching And Learning(CTL)dengan baik.Menyiapkan bahan-bahan yang akan digunakan dalam pembelajaran.Menyusun format penilaian.Merancang skenario model pembelajaran Contextual Teaching And Learning(CTL).

\section{b. Pelaksanaan Tindakan I}

Adapun yang dilakukan guru dalam pelaksanaan tindakan I adalah menerapkan langkah-langkah model pembelajaran Contextual Teaching And Learning (CTL).

c. Observasi/Pengamatan Siklus I

Dari kegiatan obesevasi pada siklus I didapat data yakni dari 20 orang siswa baru 11 siswa dinyatakan tuntas dan 9 siswa dinyatakan belum tuntas hal tersebut terlihat dari rata-rata nilai yang diperoleh yakni 71,60 dengan prosentase ketuntasan belajar 55,00\% .

\section{d. Refleksi Siklus I}

Refleksi merupakan kajian secara menyeluruh tindakan yang telah dilakukan berdasarkan data yang telah terkumpul, kemudian dilakukan evaluasi guna menyempurnakan tindakan. Refleksi menyangkut analisis, sintesis, dan penilaian terhadap hasil pengamatan atas tindakan yang dilakukan (Hopkin, 1993 dalam Suharsimi Arikunto, Suhardjono, Supardi, 2006: 80).

Analisis kuantitatif Prestasi belajar siswa siklus I

1. Rata-rata (mean) dihitung dengan: $\frac{\text { Jumla } h \text { nilai }}{\text { Jumla } h \text { siswa }}=\frac{1432}{20}=$ 71,60

2. Median (titik tengahnya) dicari dengan mengurut data/nilai siswa dari yang terkecil sampai terbesar. Untuk median yang diperoleh dari data siklus II dengan menggunakan cara tersebut adalah 73 .

3. Modus (angka yang paling banyak/paling sering muncul) setelah diasccending/diurut. Angka tersebut adalah 61.

4. Untuk persiapan penyajian dalam bentuk grafik maka halhal berikut dihitung terlebih dahulu.

1. Banyak kelas $(\mathrm{K})=1+$ 3,3 $x \log (\mathrm{N})=1+3,3 \times$ $\log 20=1+3,3 \times 1,30$ $=1+4,29=5,29 \rightarrow 6$

2. Rentang kelas $(r)=$ skor maksimum - skor minimum $=81-61=20$ 
3. Panjang kelas interval (i)

Tabel 01. Data Kelas Interval Siklus I

\begin{tabular}{|c|c|c|c|c|}
\hline $\begin{array}{l}\text { No } \\
\text { Ur } \\
\text { ut }\end{array}$ & $\begin{array}{c}\text { Inter } \\
\text { val }\end{array}$ & $\begin{array}{c}\text { NilaiTen } \\
\text { gah }\end{array}$ & $\begin{array}{c}\text { FrekuensiA } \\
\text { bsolut }\end{array}$ & $\begin{array}{c}\text { FrekuensiR } \\
\text { elatif }\end{array}$ \\
\hline 1 & $\begin{array}{c}61- \\
64\end{array}$ & 62.5 & 4 & 20.00 \\
\hline 2 & $\begin{array}{c}65- \\
68\end{array}$ & 66.5 & 3 & 15.00 \\
\hline 3 & $\begin{array}{c}69- \\
72\end{array}$ & 70.5 & 2 & 10.00 \\
\hline 4 & $\begin{array}{c}73- \\
76\end{array}$ & 74.5 & 7 & 35.00 \\
\hline 5 & $\begin{array}{c}77- \\
80\end{array}$ & 78.5 & 2 & 10.00 \\
\hline 6 & $\begin{array}{c}81- \\
84\end{array}$ & 82.5 & 2 & 10.00 \\
\hline & Tot & & 20 & 100.00 \\
\hline
\end{tabular}

4. Penyajian dalam bentuk grafik/histogram

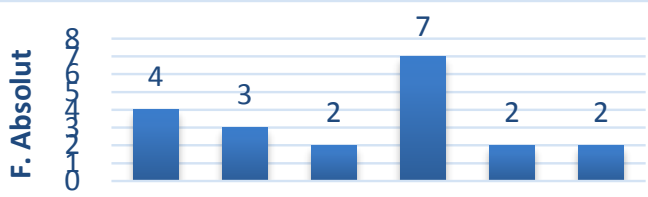

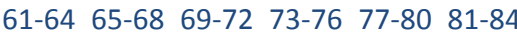

NILAI

Gambar 02. Histogram Prestasi Belajar IPSSiswa Kelas V Semester IISD No. 2 Mambal Tahun Pelajaran 2015/2016 Siklus I

Hasil kegiatan siklus I ini adalahPrestasi belajar IPS siswa kelas V semester IISD No. 2 Mambal tahun pelajaran 2015/2016 yang telah diperoleh ternyata hasilnya belum sesuai dengan harapan. Dari kegiatan observasi yang dilakukan, hanya 11 siswa yang mampu mencapai nilai KKM mata pelajaran IPS. Data tersebut menunjukkan bahwa masih banyak siswa yang belum mampu menerima dan memahamai pelajaran yang diajarkan dan hasil ini menunjukkan bahwa indikator ketuntasan belajar yang

$$
=\frac{r}{K}=\frac{20}{6}=3,33=4
$$

diharapkan belum mampu dicapai oleh siswa kelas V semester IISD No. 2 Mambal tahun pelajaran 2015/2016.

\section{Siklus II}

a. Rencana Tindakan II

Pada siklus II ini direncanakan halhal sebagai berikut :Menyusun Rencana Pelaksanaan Pembelajaran (RPP). Mempelajari langkah-langkah penggunaanmodel pembelajaran Contextual Teaching And Learning(CTL)dengan baik.Menyiapkan bahan-bahan yang akan digunakan dalam pembelajaran.Menyusun format penilaian.Merancang skenario model pembelajaran Contextual Teaching And Learning(CTL).

\section{b. Pelaksanaan Tindakan I}

Adapun yang dilakukan guru dalam pelaksanaan tindakan I adalah menerapkan langkahlangkah model pembelajaran Contextual Teaching And Learning(CTL).

\section{c. Observasi/Pengamatan II}

Hasil observasi pada siklus II didapat bahwa ada perubahan yang luar biasa terhadap prestasi belajar siswa yakni 18 siswa sudah mendapatkan nilai sesuai dengan kriteria ketuntasan maksimal dan hanya 2 siswa yang masih mendapatkan nilai dibawah KKM, rata-rata prestasi siswa mencapai 70,02 dengan prosentae ketuntasan belajar $90,00 \%$.

\section{d. Refleksi Siklus II}

Analisis kuantitatif Prestasi belajar siswa siklus II 
1. Rata-rata (mean) dihitung dengan: $\frac{\text { Jumla } h \text { nilai }}{\text { Jumla } h \text { siswa }} \quad=$ $\frac{1569}{20}=78,45$

2. Median (titik tengahnya) dicari dengan mengurut data/nilai siswa dari yang terkecil sampai terbesar. Untuk median yang diperoleh dari data siklus II dengan menggunakan cara tersebut adalah79.

3. Modus (angka yang paling banyak/paling sering muncul) setelah diasccending/diurut. Angka tersebut adalah76.

4. Untuk persiapan penyajian dalam bentuk grafik maka hal-hal berikut dihitung terlebih dahulu.

1. Banyak kelas $(\mathrm{K})=1+$ $3,3 \times \log (\mathrm{N})=1+3,3$ $\mathrm{x} \log 20=1+3,3 \mathrm{x}$ $1,30=1+4,29=5,29$ $\rightarrow 6$

2. Rentang kelas $(r)=$ skor maksimum - skor minimum $=66-86=20$

3. Panjang kelas interval (i) $=\frac{r}{K}=\frac{20}{7}=3,33 \rightarrow$ 4

Tabel 02. Data Kelas Interval Siklus II

\begin{tabular}{ccccc}
\hline $\begin{array}{c}\text { No } \\
\text { ut }\end{array}$ & $\begin{array}{c}\text { Inter } \\
\text { val }\end{array}$ & $\begin{array}{c}\text { NilaiTe } \\
\text { ngah }\end{array}$ & $\begin{array}{c}\text { FrekuensiA } \\
\text { bsolut }\end{array}$ & $\begin{array}{c}\text { Frekuensi } \\
\text { Relatif }\end{array}$ \\
\hline 1 & $\begin{array}{c}61- \\
64\end{array}$ & 67.5 & 1 & 5.00 \\
\hline 2 & $\begin{array}{c}65- \\
68\end{array}$ & 71.5 & 3 & 15.00 \\
\hline 3 & $\begin{array}{c}69- \\
72\end{array}$ & 75.5 & 5 & 25.00 \\
\hline 4 & $\begin{array}{c}73- \\
76\end{array}$ & 79.5 & 5 & 25.00 \\
\hline 5 & $77-$ & 83.5 & 3 & 15.00 \\
\hline
\end{tabular}

\begin{tabular}{ccccc}
\hline \multicolumn{5}{c}{80} \\
\hline 6 & $81-$ & 87.5 & 3 & 15.00 \\
& 84 & & & \\
\hline \multicolumn{3}{c}{ Total } & 20 & 100.00 \\
\hline
\end{tabular}

4. Penyajian dalam bentuk grafik/histogram

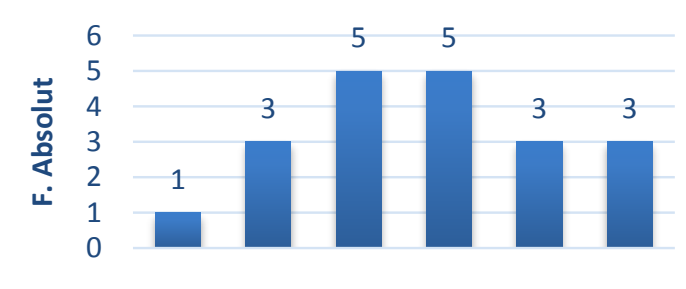

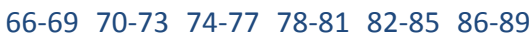

$$
\text { NILAI }
$$

Gambar 03. Histogram Prestasi Belajar IPS Siswa Kelas V Semester IISD No. 2 Mambal Tahun Pelajaran 2015/2016 Siklus II

Pelaksanaan penelitian pada siklus IIpada siswa kelas V semester IISD No. 2 Mambal tahun pelajaran 2015/2016ternyata hasilnya sudah sesuai dengan harapan. Upaya perbaikan telah dapat dilaksanakan dengan maksimal, keefektifan waktu bealjar sudah mampu diupayakan dan terlihat siswa sudah sangat senang dalam belajar. Semua kekurangankekurangan yang ada sudah diperbaiki pada siklus ini, sehingga tidak ada yang masih perlu diragukan bahwa indikator yang dituntut untuk diselesaikan tidak ada lagi yang tertinggal. Semua hasil yang diperoleh pada Siklus II ini menunjukkan bahwa penelitian ini sudah berhasil dan tidak perlu dilanjutkan kembali walaupun belum bisa dilaksanakan secara sempurna.

\section{Pembahasan}




Pada bagian ini
akanmenyampaikan
sebagai berikut.

1. Rendahnya pencapaian prestasi siswa di kelas V semester IISD No. 2 Mambal tahun pelajaran 2015/2016 dikarenakan akibat penggunaan pembelajaran yang masih konvensional yang biasa dilakukan sehari-hari tanpa mau melakukan perubahan, sehingga nilai rata-rata awal 68,15. Dari nilai tersebut, ada 6 siswa memperoleh nilai rata-rata KKM dan masih ada siswa yang memperoleh nilai di bawah KKM yaitu 14orang. Dari hasil tersebut diperoleh ketuntasan belajar $30,00 \%$

2. Pembahasan Hasil yang Diperoleh dari Siklus I

Banyaknya faktor yang menyebabkan prestasi belajar siswa menjadi rendah seperti, belum akitfnya siswa dalam belajar, siswa masih terbiasa menunggu dan belum giat untuk menemukan sendiri apa yang tertera dalam materi. Dari hasil penelitian pada siklus I diperoleh nilai rata-rata siswa di siklus I sebesar 71,60 menunjukkan bahwa siswa belum menguasai materi yang diajarkan secarabaik. Walaupun demikian, hasil ini sudah menunjukkan peningkatan kemampuan siswa dari data awal ke siklus I.Namun prestasi belajar yang dicapai pada siklus I ini belum memenuhi harapan sesuai dengan kriteria ketuntasan belajar serta kriteria keberhasilan penelitian yang diusulkan.Indikator keberhasilan yang dituntut adalah rata-rata hasil belajar siswa telah memenuhi minimal nilai KKM 73dengan ketuntasan belajar minimal $80 \%$. Oleh karenanya upaya perbaikan lebih lanjut masih perlu diupayakan sehingga perlu dilakukan perencanaan yang lebih matang untuk siklus selanjutnya dengan melakukan perbaikan.

3. Pembahasan Hasil yang Diperoleh dari Siklus II

Hasil yang diperoleh dari tes prestasi belajar di siklus II ternyata menunjukkan peningkatan kemampuan siswa dalam mengikuti pelajaran. Ini terbukti dari rata-rata nilai siswa sudah mencapai 78,45. Hasil ini menunjukkan Model pembelajaran Contextual Teaching And Learning(CTL)telah berhasil meningkatkan kemampuan siswa menempa ilmu sesuai harapan. Model pembelajaran Contextual Teaching And Learning(CTL)merupakan model yang cocok bagi siswa apabila guru menginginkan mereka memiliki pengetahuan yang lebih baik, kemampuan berkreasi, berbicara, mengeluarkan pendapat, bertukar pikiran, mengupayakan kemampuan yang tinggi untuk siswa dapat berinteraksi dengan materi, berinteraksi dengan sesama siswa, dengan guru serta dengan materi.Dari kegiatan tindakan pada siklus II ini adalah pengaruhnya terhadap prestasi belajar siswa dengan dibutikan dari peningkatan prestasi belajar siswa sehingga 
penelitian ini tidak perlu dilanjutkan kesiklus berikutnya.

\section{PENUTUP}

\section{Simpulan}

Pelaksanaan kegiatan penelitian pada Siswa Kelas V Semester IISD No. 2 Mambal Tahun pelajaran 2015/2016 mata pelajaran IPS dari kegiatan awal, kegiatan siklus I, dan kegiatan siklus II, serta sesuai dengan data hasil penelitian dan analisis deskriptif yang telah dilaksanakan memberikan kesimpulan bahwa : Model pembelajaran Contextual Teaching And Learning(CTL) telah dapat membuktikan bahwa guru dan siswa menjadi sangat aktif dalam pembelajaran. Semua kebehasilan itu telah dapat ditunjukkan dengan data yang telah diperoleh dalam analisis di Bab IV. Pandangan di atas telah dibuktikan pada kegiatan pembelajaran dalam penelitian ini dan prestasi belajar siswa semakin meningkat dari data awal rata-rata prestasi belajar siswa hanya sebesar 68,15 dengan presentase ketuntasan belajar $30,00 \%$, pada siklus I terjadi peningkatan rata-rata prestasi belajar siswa menjadi 71,60 dengan presentase ketuntasan belajar $55,00 \%$ dan pada siklus II diperoleh ratarata sebesar 78,45 dengan presentase ketuntasan belajar 90,00\%.Dari uraian yang telah disampaikan diatas maka dapat disampaikan kesimpulan bahwa penggunaan Model pembelajaran Contextual Teaching And Learning(CTL) dengan optimal dapat meningkatkan prestasi belajar IPS Siswa Kelas V Semester IISD No. 2 Mambal Tahun pelajaran 2015/2016.
Berdasarkan bukti keberhasilan penelitian yang telah disampaikan pada simpulan menjadi pedoman peneliti untuk menyampaikan saran sebagai berikut:Kepada teman guru pengajar mata pelajaran IPS disarankan untuk mencoba menggunakan Model pembelajaran Contextual Teaching And Learning(CTL).Kepada pengawas sekolah agar dalam membina guru agar menyarankan untuk menggunakan Model pembelajaran Contextual Teaching And Learning(CTL).Selanjutnya untuk adanya penguatan-penguatan, diharapkan bagi peneliti lain untuk melakukan penelitian lanjutan guna menyempurnakan data hasil penelitian ini.

\section{DAFTAR PUSTAKA}

Abimanyu, Soli dkk. (2008). Strategi Pembelajaran. Jakarta : Direktorat Jendral Pendidikan Tinggi Departemen Pendidikan Nasional

Abin Syamsuddin Makmun. (2000). Psikologi Kependidikan. Bandung: Remaja Rosda Karya.

Arikunto, S.; Suhardjono; Supardi. (2006). Penelitian Tindakan Kelas. Jakarta: PT Bumi Aksara.

Bustalin, (2004) Psikologi Belajar Mengajar.Bandung: CV. Mandar Maju.

Depdiknas. (2002). Contextual Teaching And Learning. Jakarta: Dirjen Pendidikan Dasar dan Menengah.

Johnson Elaine B. (2002). Contextual Teaching \& Learning Menjadikan Kegiatan Belajar-Mengajar Mengasyikkan dan Bermakna. Bandung: MLC

Masnur Muslich. (2011). Melaksanakan PTK Itu Mudah. Jakarta: Bumi Aksara.

\section{Saran}


